\title{
Novel Cdc42-binding proteins Gicl and Gic2 control cell polarity in yeast
}

\author{
Jeffrey L. Brown, ${ }^{1,3}$ Malika Jaquenoud, ${ }^{2}$ Marie-Pierre Gulli, ${ }^{2}$ John Chant, ${ }^{1}$ and Matthias Peter,4 \\ ${ }^{1}$ Department of M olecular and Cellular Biology, Harvard University, Cambridge, Massachusetts 02138 USA; ${ }^{2}$ Institut Suisse \\ de Recherches Expérimentales sur le Cancer (ISREC), 1066 Epalinges/VD Switzerland
}

\begin{abstract}
Cdc42p, a Rho-related GTP-binding protein, regulates cytoskeletal polarization and rearrangements in eukaryotic cells, but the effectors mediating this control remain unknown. Through the use of the complete yeast genomic sequence, we have identified two novel Cdc42p targets, Giclp and Gic2p, which contain consensus Cdc42/Rac interactive-binding (CRIB) domains and bind specifically to Cdc42p-GTP. Giclp and Gic2p colocalize with Cdc42p as cell polarity is established during the cell cycle and during mating in response to pheromones. Cells deleted for both GIC genes exhibit defects in actin and microtubule polarization similar to those observed in cdc42 mutants. Finally, the interaction of the Gic proteins and Cdc42p is essential, as mutations in the CRIB domain of Gic2p that eliminate Cdc42p binding disrupt Gic2p localization and function. Thus, Giclp and Gic2p define a novel class of Cdc42p targets that are specifically required for cytoskeletal polarization in vivo.
\end{abstract}

[Key Words: Polarization; cytoskeleton; Rho GTPases; Saccharomyces cerevisiae]

Received July 25, 1997; revised version accepted September 9, 1997.

In polarized cells, the actin and microtubule cytoskeletons are highly asymmetric and serve to spatially regulate various cellular functions, including targeted secretion, signaling, and nuclear migration (Glotzer and $\mathrm{Hy}$ man 1995; Chant 1996; Drubin and Nelson 1996). The actin cytoskel eton maintains cell shape and plays a pivotal role in cell motility, cytokinesis, and phagocytosis. Reorganization of the actin cytoskeleton is regulated both through the cell cycle and in response to extracelIular signals. Members of the Rho family of small GTPases have emerged as key regulators of actin filament dynamics and the assembly of focal adhesion contacts (Hall 1994; Ridley 1995). Rho GT Pases are also important for maintaining cellular transformation (Symons 1995). GTPases act as molecular switches cycling between GTP- and GDP-bound conformations. When in the GTP-bound conformation, GTPases are thought to interact with target proteins that mediate their effects.

Cdc42p, a highly conserved Rho-type GTPase, has been shown to control polarized axis formation in both yeast and mammalian cells (Johnson and Pringle 1990; Hall 1994; Stowers et al. 1995). In fibroblasts, microinjection of activated Cdc42p triggers formation of filopodia or microspikes at the cell periphery (Kozma et al. 1995; Nobes and Hall 1995). In yeast, Cdc42p controls the polarization of actin and microtubules during both

${ }^{3}$ Present address: Millenium Pharmaceuticals Inc., Cambridge, Massa chusetts 02139 USA.

${ }^{4}$ Corresponding author.

E-MAIL matthias.peter@isrec.unil.ch; FAX (41) 21 652-6933. the vegetative cell cycle and mating. Polarity is initiated by choosing a site on the surface of the cell, and then growth is directed toward this site. During vegetative growth by budding, polarization is directed by a celltype-specific program, which is controlled by a group of nonessential genes (BUD1-BUD9, AXL1, and BUD10/ AXL2; Chant 1996). During mating, polarization is directed toward the mating partner by a mechanism involving the FAR1 gene (Dorer et al. 1995; Valtz et al. 1995). Remodeling of the actin cytoskeleton toward these sites during both budding and mating requires the products of multiple genes, including BEM 1, CDC24, and CDC42. CDC24 encodes a GDP-GTP exchange factor for Cdc42p (Sloat and Pringle 1979; Zheng et al. 1994). Bem 1p contains two SH 3 domains and is thought to provide a scaffold by interacting di rectly with Cdc42p, Cdc24p, Ste20p, and Ste5p (Peterson et al. 1994; Leeuw et al. 1995; Lyons et al. 1996; Park et al. 1997). Cdc42p and Bemlp localize to the sites of polarized growth: the bud site during the cell cycle and the shmoo tip in cells exposed to pheromones (Ziman et al. 1993; Pringle et al. 1995). Cells lacking C dc42p or C dc24p function are unable to polarize their cytoskel eton and, as a consequence, arrest as large unbudded cells (Adams et al. 1990). In contrast, cells deleted for BEM 1 are viable but exhibit morphological abnormalities (Chenevert et al. 1992).

In addition, $\mathrm{Cdc} 42 \mathrm{p}$ has been shown to function upstream of mitogen-activated protein (MAP) kinase signal transduction pathways. In mammalian cells, Cdc42p triggers the Jun amino-terminal kinase/stress-activated protein kinase (JN K/SAPK) cascade (Bagrodia et al. 1995; Coso et al. 1995; Hill et al. 1995; Minden et al. 1995) and 
has also been implicated in the activation of the $p 70^{56}$ kinase (Chou and Bl enis 1996). In yeast, Cdc42p has been suggested to play a role in MAP kinase signaling pathways during mating (Simon et al. 1995; Zhao et al. 1995) and during pseudohyphal growth (Mösch et al. 1997). Members of the p21-activated kinase family (PAK) appear to be important effectors, mediating at least part of the signaling role of Cdc42p (Manser et al. 1994; Zhang et al. 1995; Brown et al . 1996; Peter et al. 1996; Leberer et al. 1997). Binding of Cdc42p to PAK-like kinases occurs through a short segment that is conserved among several Cdc42p targets and has been termed the Cdc42/Rac-interactive-binding (CRIB) domain (Burbelo et al. 1995). Activation of PAK kinases, however, is neither necessary nor sufficient for cytoskeletal polarization mediated by Cdc42p (Joneson et al. 1996; Lamarche et al. 1996).

The effectors of $\mathrm{Cdc} 42 \mathrm{p}$ that control the cytoskeleton remain unknown. Although a number of candidate effectors have recently been described in yeast and mammals, none of these proteins can fully account for the effects of Cdc42p on cell polarization. The protein altered in patients suffering from Wiskott-Aldrich Syndrome (WASP) is important for some aspects of actin organization (Aspenstrom et al. 1996; Kolluri et al. 1996; Symons et al. 1996), but experiments in yeast have shown that the WASP-related molecule Las17/Beel is dispensiblefor cell polarization (Li 1997; D. Mitchell and G. Sprague, pers. comm). The formin-related proteins Bnilp and Bnrlp bind to several Rho-related GTPases, and thus may not act as specific C dc42p targets (Kohno et al. 1996; Evangel ista et al. 1997; Imamura et al. 1997). IQGAP family molecules, which are related by sequence to GTPase activating proteins (GAP), represent a possible class of Cdc42p effectors (Brill et al. 1996; Hart et al. 1996; Kuroda et al. 1996; M cCallum et al. 1996), but our recent work suggests that yeast cells deleted for the gene, IQG1, encoding an IQGAP-related molecule are able to polarize (Epp and J. Chant, unpubl.). Finally, the ACK tyrosine kinase remai ns a largely unexplored mammalian target of Cdc42p (Manser et al 1994); however, ACK is not present in yeast and, therefore, seems an unlikely candidate for an ubiquitous Cdc42p effector involved in cytoskeletal polarization.

To identify Cdc42p effectors important for cytoskeletal polarization, we searched the compl ete Saccharomyces genomic sequence for additional proteins containing a CRIB domain. In this paper, we describe two novel Cdc42p effectors, Giclp and Gic2p, which bind specifically to Cdc42p-GTP through their conserved CRIB domain. Importantly, Giclp and Gic2p are required for cell polarization in vivo during the cell cycle and in response to extracellular signals, but they are dispensable for MAP kinase signal transduction. Our data suggest that Giclp and Gic2p specifically link Cdc42p to dynamic rearrangements of the actin and microtubule cytoskeletons.

\section{Results}

Identification of GIC1 and GIC2

To identify potential C dc42p targets, the compl ete geno- mic sequence of Saccharomyces cerevisiae was searched for gene products that contain the CRIB domain, which is shared by a number of known Cdc42p effectors (Manser et al. 1994; Burbelo et al. 1995) (Fig. 1A). Five proteins were identified: three PAK-rel ated serine/threonine kinases (Ste20p, Cla4p, and Skmlp; Leberer et al. 1992; Ramer and Davis 1993; Cvrckova et al. 1995) and two uncharacterized open reading frames, which we denoted GIC1 and GIC2 (GTPase interactive components $\underline{1}$ and 2 ). Giclp and Gic $\overline{2 p}$ are related proteins of similar size with a highly conserved amino-terminal region followed by the CRIB domain and a less conserved carboxyl terminus (Fig. 1B). Further database searches indicated that Giclp and Gic2p define a new class of CRIB domain proteins, and that there are only two Gic family members in yeast.

\section{Giclp and Gic2p bind specifically to Cdc42p-GTP in} vitro and in vivo

We tested whether the Gic proteins bind directly to Cdc42p by both biochemical and two-hybrid experiments. Columns containing immunoaffinity-purified Gic2 protein were assayed for their ability to retain recombinant Cdc42p. As illustrated in Figure 2A, Cdc42p preloaded with GTP $\gamma S$ readily bound to the Gic $2 p$ column, whereas Cdc42p-GDP exhibited no detectable affinity. Recombinant Cdc42p containing a T35A mutation in the GTPase effector domain, preloaded with GTP $\gamma$ S, failed to interact with Gic2p, suggesting that the interaction between Gic $2 p$ and Cdc42p occurs through the effector domain of C dc42p.

The specificity of these interactions, particularly in relation to other Rho-type GTPases, was further examined by the two-hybrid system (Fields and Song 1989) (Table 1). Strong interactions were detected between the GTP-bound form of Cdc42p (G12V) and both Gic proteins, whereas no interaction was observed with the GDP-bound form of Cdc42p (D118A). Importantly, neither Bemlp nor any of the related Rho GTPases of yeast interacted with Gic2p, showing that Gic2p is a specific binding partner of Cdc42p. Mutating three conserved residues in the CRIB consensus sequence ( $\left.\mathrm{Gic} 2 \mathrm{p}^{\mathrm{crib}-}\right)$ to alanine residues abol ished the interaction with $C d c 42 p$, showing that the interaction between Gic2p and Cdc42p requires an intact CRIB domain.

Further evidence showing an in vivo interaction be tween the Gic proteins and Cdc42p is illustrated in Figure 2B. Overproduction of a Gic2p fragment (Gic2 $p^{1-208}$ ), containing the CRIB domain, interferes in a dominantnegative fashion with cell growth. This growth defect was suppressed by overproduction of $C d c 42 p$, but not by overproduction of $\mathrm{Cdc} 42 \mathrm{p}^{\mathrm{T} 35 \mathrm{~A}}$, a related GTPase (Rholp), proteins involved in cell polarity (Cdc24p or Bemlp), or the established Cdc42p target, Cla4p. The simplest interpretation of this result is that overproduction of the Gic2p fragment competes for active Cdc42p within the cell, thereby preventing proper regulation of endogenous Cdc42p targets. Additional Cdc42p overcomes this deficiency. The restoration of growth by 
Brown et al.

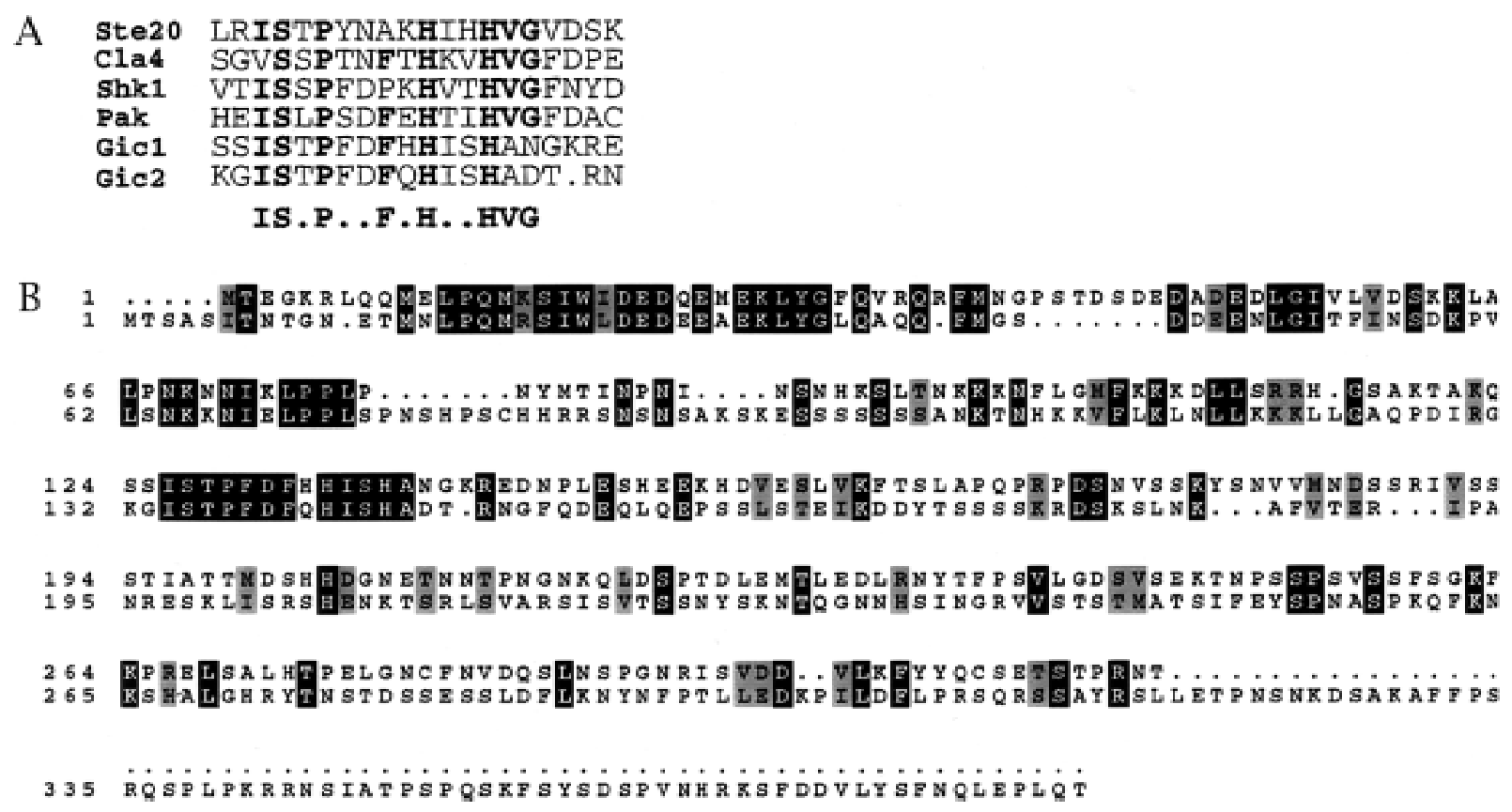

Figure 1. Giclp and Gic2p, two novel Cdc42p binding proteins. (A) Alignment of the CRIB domains of Giclp and Gic2p to several Ste20/PAK-related kinases. Consensus amino acid residues are shown in bold (Burbelo et al. 1995). Sequences are from the following sources: Ste20p and Cla4p (Leberer et al. 1992; Ramer and Davis 1993; Cvrckova et al. 1995), Shk1p (M arkus et al. 1995), and PAK1 (M anser et al. 1994). (B) Alignment of Giclp (top) and Gic2p. Identical amino acid residues are indicated with black boxes. Similar amino acids are shaded.

Cdc42p, but not by Cdc42p $\mathrm{p}^{\mathrm{T} 3 \mathrm{~A}}$, supports this view and suggests that Gic $2 p$ binds the Cdc42p effector domain. Taken together, the in vitro binding data, two-hybrid analysis, and genetic suppression experiments show that
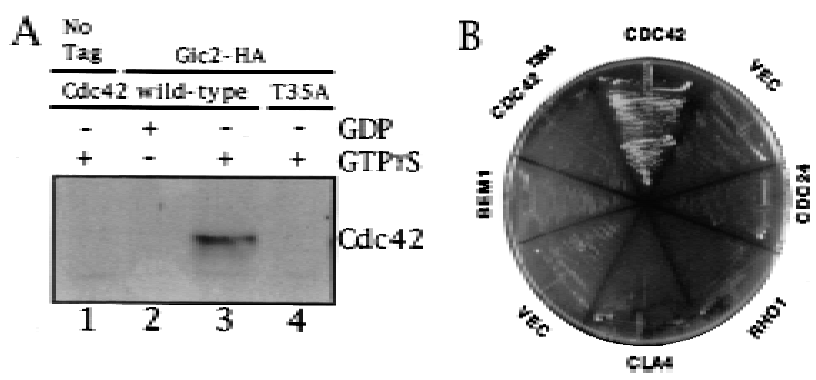

Figure 2. Giclp and Gic2p bind Cdc42p-GTP. (A) Gic2p binds to Cdc42p-GTP. Sepharose beads containing purified yeast Gic2p were assayed for their ability to retain E. coli expressed Cdc42p prel oaded with either GTP $\gamma$ S (Ianes 1,3,4), or GDP (lane 2). (Lane 1) Control beads. (Lanes 2-4) Gic2-HAp beads. The following Cdc42 proteins were analyzed: (Lanes 1-3) wild-type Cdc42p. (Lane 4) Cdc42p ${ }^{\top 35 A}$. Cdc42p was detected by immunoblotting. (B) Overproduction of an amino-terminal fragment of Gic2p inhibits cell growth (overexpressed from the GAL1 promoter). Cells accumulate with a large unbudded morphology. This growth defect could be suppressed by a high-copynumber plasmid carrying CDC 42, but not by high-copy-number plasmids carrying no insert (VEC), CDC24, RHO1, CLA4, BEM 1, or CDC $42^{\text {T35A }}$.
Giclp and Gic2p interact specifically with GTP-bound Cdc42p in vivo.

Gic2p is produced in a cell cycle-dependent manner

We examined whether the Gic proteins were present during the $G_{1}$ phase of the cell cycle when C dc42p directs cell polarity. Temperature-sensitive cdc15 cells were arrested in late mitosis and released from the cell cycle block by shifting the culture to the permissive temperature. As shown in Figure 3A, Gic2p accumulated throughout the $\mathrm{G}_{1}$-phase and peaked at the time of polarity establishment (15 min prior to bud emergence; $\mathrm{BE}$ in Fig. 3A). Gic2p rapidly disappeared at the time of bud emergence, concomitant with the appearance of $C \ln 2 p$ (Fig. 3B). No Gic2 protein was detected in $\mathrm{G}_{2}$ cells. In contrast, $C$ dc $42 p$ levels remained constant throughout the time course (data not shown; Ziman et al. 1993). We conclude that Gic2p is expressed in a cell cycle-dependent manner reaching maximal levels in late $\mathrm{G}_{1}$, consistent with a role in the establishment of cell polarity.

Giclp and Gic2p colocalize with Cdc42p to regions of polarized cell growth

N ext, we determined the subcellular localization of the Gic proteins (Fig. 4). As axes of cell polarity are being established, Giclp and Gic2p were found to be asymmetrically distributed in patterns similar to that of Cdc42p. During cell division, Gic1p and Gic2p localized 
Table 1. Two-hybrid interactions between the Gic proteins, Bem1p, and Rho-family GTPases

\begin{tabular}{llc}
\hline $\begin{array}{l}\text { DNA-binding } \\
\text { domain } \\
\text { fusion }{ }^{\text {a }}\end{array}$ & \multicolumn{1}{c}{$\begin{array}{c}\text { Activation } \\
\text { domain } \\
\text { fusion }\end{array}$} & $\begin{array}{c}\text { lacZ } \\
\text { expression }\end{array}$ \\
\hline Cdc42p & vector & (Miller units) \\
Cdc42p & Gic2p (full length) & 49 \\
Cdc42p & Gic2p (1-208) & 1503 \\
Cdc42p & Gic1p (1-176) & 1616 \\
Cdc42p & Gic2p (Crib-) & 1530 \\
Cdc42p (D118A) & & 50 \\
GDP bound & vector & \\
Cdc42p (D118A) & Gic2p (full length) & 9 \\
Cdc42p (G12V) & & 11 \\
GTP bound & vector & 151 \\
Cdc42p (G12V) & Gic2p (full length) & 1372 \\
Rho1p & vector & 22 \\
Rho2p & vector & 24 \\
Rho3p & vector & 18 \\
Rho4p & vector & 27 \\
Rho1p & Gic2p (full length) & 17 \\
Rho2p & Gic2p (full length) & 14 \\
Rho3p & Gic2p (full length) & 15 \\
Rho4p & Gic2p (full length) & 7 \\
Bem1p & vector & 8 \\
Bem1p & Gic2p (full length) & 12 \\
\hline
\end{tabular}

aThe LexA DNA binding domain fusions were carried on pEG202 and contain the carboxy-terminal Cys-Ser substitutions, which prevent prenylation (Stevenson et al. 1995).

bThe activation domain fusions were carried on pJG4-5, and pJ G4-5 provided the vector control.

'The average Miller units expressed of the lexA-lacZ reporter from three independent experiments are presented.

to the future bud site and later to the surfaces of smal I buds, as visualized by immunofluorescence microscopy (Fig. 4A). Cdc42p has been shown previously to localize to these same regions of polarized growth (Ziman et al.

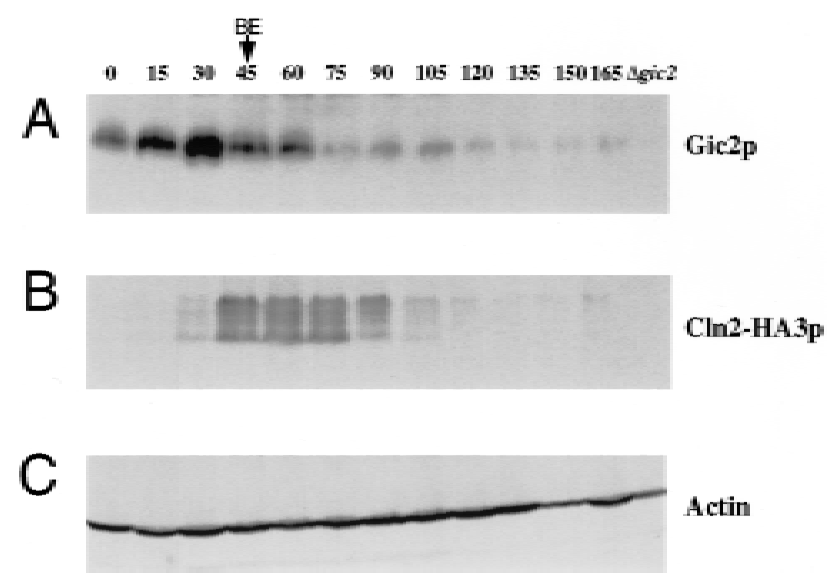

Figure 3. Gic2p is expressed in a cell cycle-dependent manner. Cells were synchronized by releasing temperature-sensitive cdc15 cells from their block in late mitosis. Aliquots were collected every $15 \mathrm{~min}$ and analyzed by immunoblotting. The time of bud emergence is indicated as BE. (A) Gic2p; (B) CIn2p; (C) actin.

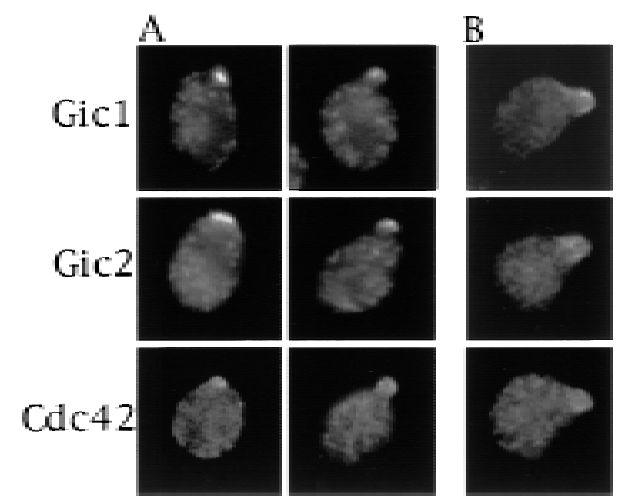

Figure 4. Giclp and Gic2p colocal ize with Cdc42p to regions of polarized growth. Epitope-tagged Giclp, Gic2p, and Cdc42p, expressed from their native promoters on centromeric plasmids, were detected by indirect immunofluorescence. Giclp, Gic2p, and $\mathrm{Cdc} 42 \mathrm{p}$ proteins localize to the incipient bud site and the surfaces of small buds (A), and to the tips of polarized mating projections (B).

1993). No localized Gic1p, Gic2p, or Cdc42p was observed in cells with medium to large buds; however, on occasion, some Cdc42p or Gic protein could be seen in the mother-bud neck very late in the cell cycle (data not shown). During mating, Giclp, Gic2p, and Cdc42p colocalized to the tips of mating projections (shmoos) (Fig. 4B). Thus, Giclp and Gic2p, together with Cdc42p, are located in regions that direct cytoskel etal polarization.

Giclp and Gic2p are functionally redundant proteins necessary for cell polarization in vivo

To determine whether the Gic proteins play a role in cell polarization, we studied the effects of GIC1 and GIC2 null mutations. As Giclp and Gic2p are closely related by sequence, it seemed likely that the two genes would be functionally redundant. Consistent with this prediction, strains carrying either the GIC1 or GIC2 deletion grew normally, but strains deleted for both $\mathrm{GICl}$ and GIC2 were slow growing at $23^{\circ} \mathrm{C}$ and $30^{\circ} \mathrm{C}$, and were dead at $37^{\circ} \mathrm{C}$ (Fig. 5A, data not shown). In a population of double mutants at $30^{\circ} \mathrm{C},>80 \%$ of the cells accumulated as large, unbudded, multinucleate cells (Fig. 5D,I). Examination of both actin and microtubules in these mutants showed that the morphological defects reflected an underlying deficiency in cytoskeletal polarization. Whereas wild-type cells and the single gic mutant strains budded and pol arized actin normal ly (Fig. 5B,C; data not shown), gic1 $\Delta$ gic $2 \Delta$ double mutants were deficient in actin polarization with actin patches distributed randomly at the cell cortex and actin cables either absent or misaligned (Fig. 5E). Spindle alignment in gicl $\Delta$ gic2 $\Delta$ cells was also aberrant (Fig. 5H). Thus, cells lacking Gic proteins exhibit defects in cell polarization similar to those observed in cells lacking C dc42p function (Adams et al. 1990). 
Figure 5. Giclp and Gic2p encode redundant proteins required for efficient growth and cell polarization in vivo. (A) Strains harboring del etions in GIC1 or GIC2 grow at rates indistinguishable from the wildtype parental strain. Strains deleted for both $\mathrm{GIC} 1$ and $\mathrm{GIC} 2$ grow slowly at $30^{\circ} \mathrm{C}$. (B-I) Wild-type $(B, C, F, G)$ and gicls gic $2 \Delta$ cells $(D, E, H, I)$ were observed by DIC $(B, D)$ and epifluorescence microscopy (C,E,F-I). Actin $(C, E)$, DNA $(F, I)$, and microtubules $(\mathrm{G}, \mathrm{H})$ are shown.
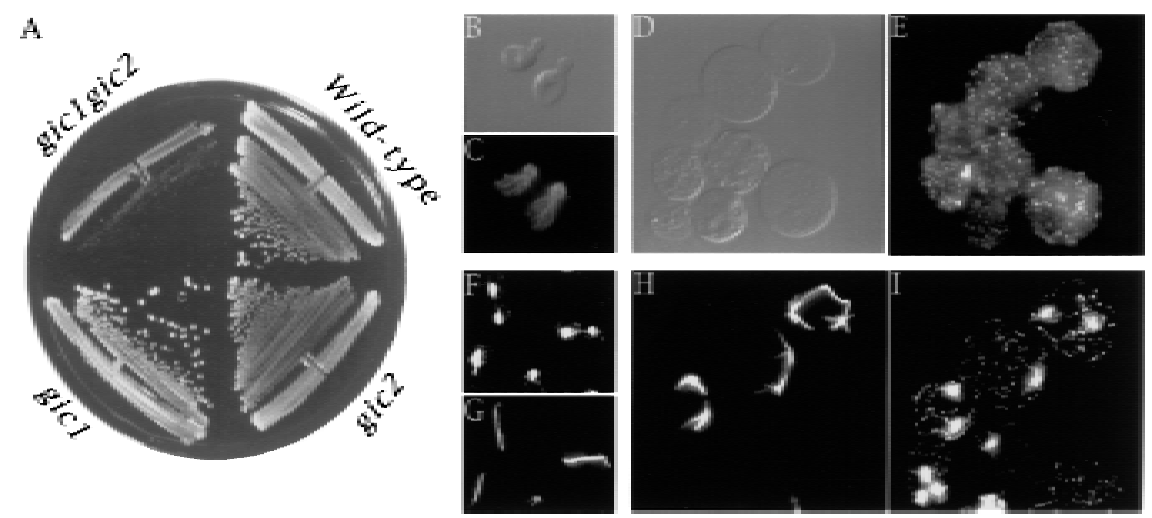

Giclp and Gic2p are required for polarized morphogenesis but not MAP kinase signal transduction during mating

Cdc42p has been implicated in both cell polarization and MAP kinase signal transduction during yeast mating (Zhao et al. 1995; Simon et al. 1995; Stevenson et al. 1995). To determi ne whether the Gic proteins play a role in signal transduction, we measured transcriptional induction and cell cyclearrest in response to mating pheromones, both readouts of MAP kinase signaling (Herskowitz 1995). When exposed to pheromone, the gicls gic2 $\Delta$ strains induced wild-type levels of the transcriptional reporter FU S1-LacZ (Trueheart et al. 1987) and were unaffected for cell cycle arrest (Fig. 6A,B). Thus, the Gic proteins are not required to activate the MAP kinase pathway during yeast mating. In contrast to wild-type cells, however, gicl $\Delta$ gic $2 \Delta$ cells did not form polarized mating projections (shmoos) in response to mating pheromones (Fig. 6C) and, consequently, exhibited a 100fold decrease in mating efficiency (Fig. 6D). Thus, Giclp and Gic2p are unlikely to mediate any effect of Cdc42p on MAP kinase signal transduction, but they are important effectors of Cdc42p for the establishment of cell polarity during mating, as well as during vegetative growth.

\section{Binding of Gic2p to Cdc42p is essential to Gic2p function in vivo}

To assess the importance of $\mathrm{Cdc} 42 p$ binding for Gic $2 p$ function in vivo, we analyzed the function of a Gic2 protein containing CRIB domain mutations that abolish detectable Cdc42p interaction ( $M$ anser et al. 1994; Burbelo et al. 1995; Peter et al. 1996; Leberer et al. 1997) (Table 1). Although the mutant protein was produced at wild-type levels (Fig. 7B), the gic $2^{\text {crib- }}$ allele was unable to complement the growth defect of the gic1 $\Delta$ gic2 $\Delta$ double mutant (Fig. 7A), showing that binding of Gic2p to Cdc42p is essential for Gic2p function in vivo. Additionally, Gic2 ${ }^{\text {crib- }}$ protein failed to concentrate efficiently at sites of polarized growth and, instead, was distributed throughout the cytoplasm (Fig. 7C). Thus, the interaction between Cdc42p and Gic2p is required for proper Gic2p function and localization. Recently, it has been shown that $C$ dc $42 p$ al so directs the localization of the protein kinase Ste20p (Peter et al. 1996; Leberer et al. 1997), suggesting that Cdc42p might generally target effectors to sites of polarized growth.

Genetic interactions between the GIC genes and other factors involved in cell polarization

In addition to Cdc42p, Bem1p and Bem2p are also in-
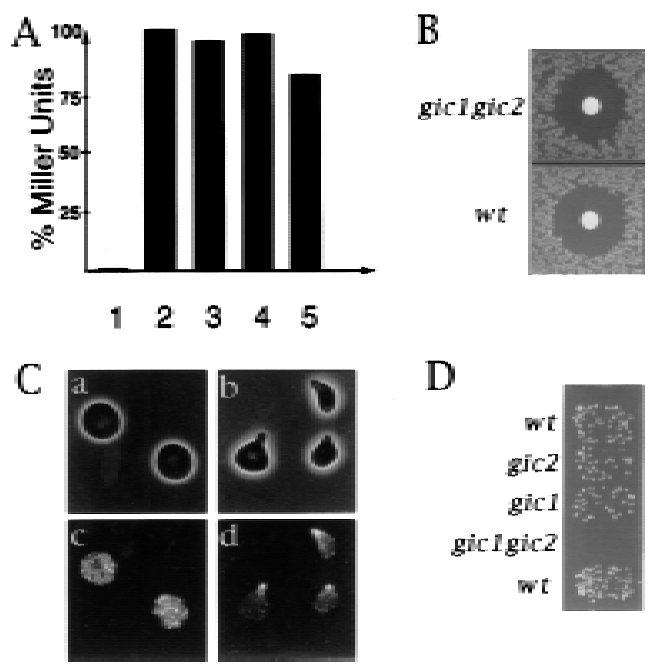

D

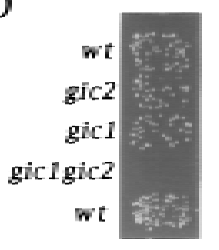

Figure 6. Giclp and Gic2p are required for polarized morphogenesis but not for MAP kinase signaling in response to pheromones. (A) Activity of the MAP kinase signaling pathway triggered by pheromones was measured by induction of the FU S1LacZ reporter, and plotted as percent Miller Units relative to wild-type controls. (Lane 1) No $\alpha$-factor added. (Lanes 2-5) $\alpha$ factor added for $1 \mathrm{hr}$. The foll lowing strains were anal yzed: (1 and 2) wild-type; (3) gicl $\Delta$; (4) gic $2 \Delta ; 5$ : gicl $\Delta$ gic $2 \Delta$. (B) gicl $\Delta$ gic $2 \Delta$ (top panel) and wild-type cells (bottom panel) are able to arrest their cell cycle in response to $\alpha$-factor as assessed by halo assay. (C) gic double mutants ( $a$ and $c$ ), but not cells lacking GIC2 (b and d), are defective for polarized morphogenesis in response to $\alpha$-factor. ( $a$ and b) Phase contrast photographs; (c and d) actin visualized by rhodamine-phalloidin. (D) Mating efficiencies of wild-type and gic mutant strains to a farl-c tester (Valtz and Peter 1997). 

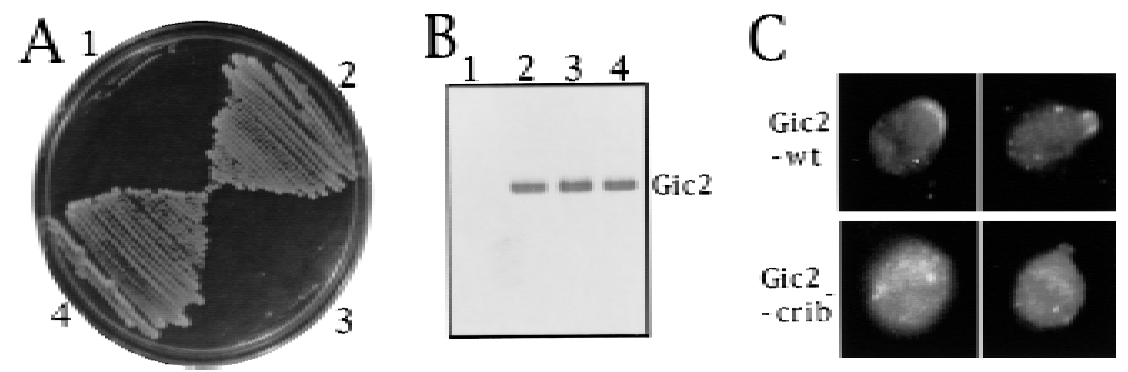

Figure 7. Interaction between Gic2p and Cdc42p is essential for Gic2p function and localization. (A) The growth defect of gicls gic $2 \Delta$ cells could be complemented by plasmids expressing wild-type GIC2 but not gic2 ${ }^{\text {crib-. }}$. (1) gic1 $\Delta$ gic $2 \Delta$ strain carrying vector. (2) gicl $\Delta$ gic $2 \Delta$ carrying vector with a GIC2 insert. (3) gic1 $\Delta$ gic $2 \Delta$ carrying vector with a gic $2^{\text {crib- }}$ insert. (4) A gic1 strain carrying no plasmid for comparison to sector 2. (B) Wild-type and Gic2 $\mathrm{p}^{\mathrm{crib}-}$ proteins are present at equal levels. Lane numbers correspond to those of panel A. Gic2 protein was detected by immunoblotting with specific Gic2pantibodies. (C) Asymmetric local ization of Gic2p is dependent on a functional CRIB domain. Localization of epitope-tagged wild-type

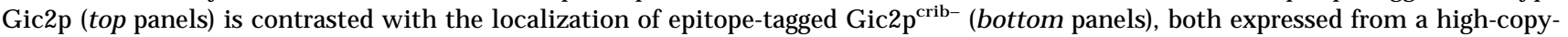
number plasmid.

volved in the establishment of cell polarity. Bem2p functions as a GA P for Rho-type GTPases (Zheng et al. 1993; Peterson et al. 1994), whereas Bemlp may provide a scaffold for several polarity establishment proteins. Because the phenotype of gic $1 \Delta$ gi $2 \Delta$ cells resembles that of cells lacking Bem1p and Bem2p, we tested whether overproduction of Giclp and Gic2p could rescue the growth defect of these cells. We found that high-copy-number vectors carrying $\mathrm{GIC} 1$, but not GIC2, partially restored growth at $37^{\circ} \mathrm{C}$ to bem $1 \Delta$ or bem $2 \Delta$ cells (Fig. $8 \mathrm{~A}$, and data not shown). Conversely, a multicopy plasmid carrying BEM 1 was able to partially rescue the growth defect of gic $1 \Delta$ gic $2 \Delta$ cells (data not shown). These results further support the view that Giclp and Gic2p are involved in polarity establishment.

Interestingly, the growth defect of gicl $\Delta$ gic $2 \Delta$ cells could also be suppressed by overproduction of wild-type Cdc42p (Fig. 8B). Overproduction of Cdc42p in its GTP- bound form interfered with cell proliferation of gicl $\Delta$ gic $2 \Delta$ cells, indicating that at least some of the lethal effects of Cdc42p-GTP are not dependent on the presence of the Gic proteins (Fig. 8B). Finally, multicopy plasmids carrying either $\mathrm{GIC} 1$ or GIC2 were not able to restore growth of a temperature-sensitive cdc42 mutant (data not shown). The simplest interpretation of these genetic suppression results is that Cdc42p controls multiple targets that coordinate cytoskeletal polarization, and that overproduction of Cdc42p can compensate, at least partially, for the lack of some effectors.

\section{Discussion}

Giclp and Gic2p are Cdc42p-specific effectors required for establishment of cell polarity

Our results identify two novel effectors of $C d c 42 p$ that are required for cellular pol arization during polarized cell
A
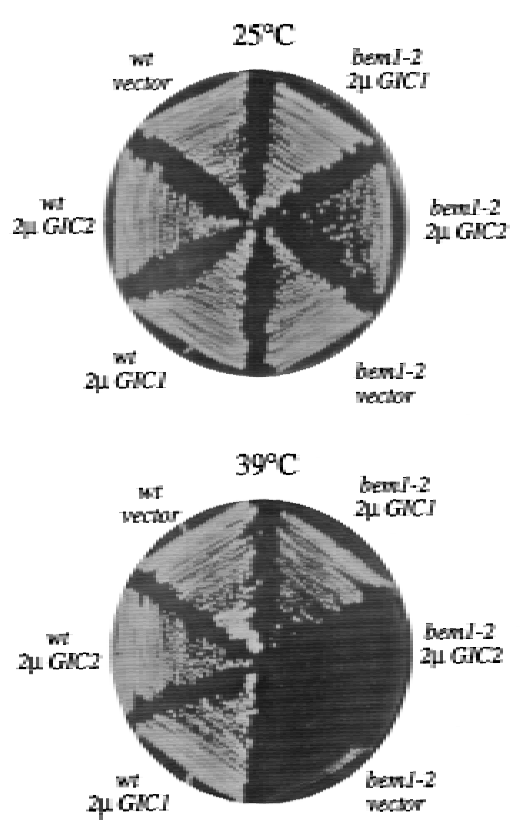

B
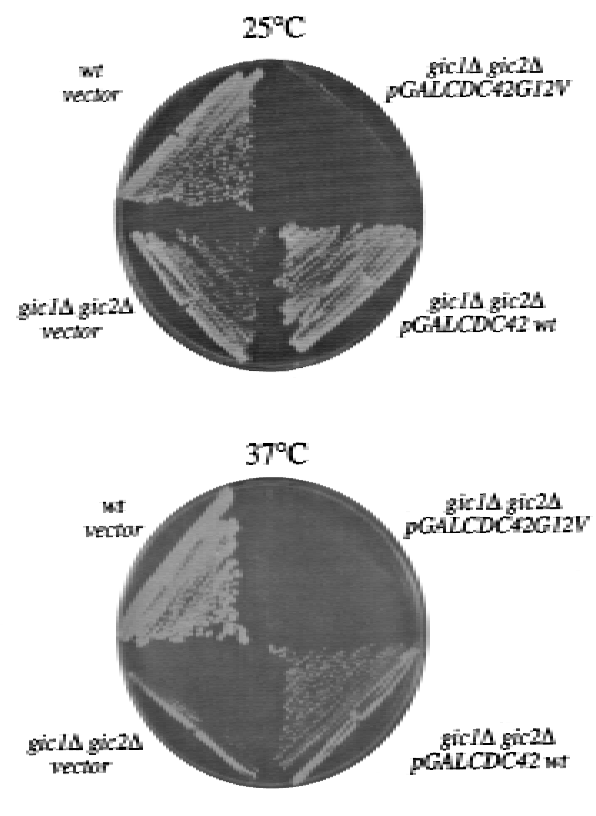

Figure 8. Genetic interaction between the Gic proteins, Bem1p, and Cdc42p. (A) Overexpression of Giclp but not Gic2p is able to partially restore growth of cells lacking Bemlp function at $39^{\circ} \mathrm{C}$. (B) Overexpression of wild-type Cdc42p but not Cdc42p in its active GTP-bound form (G12V) is able to suppress the growth defect of gicl $\Delta$ gic2 mutants at $37^{\circ} \mathrm{C}$. 
division and mating chemotropism. A number of other Cdc42p-interacting proteins have been identified previously, including PAK kinases, WASP-related factors, and formins (Symons 1996; Frazier and Field 1997). Although these molecules are suggested or shown to be Cdc42p targets, they do not appear to account for the effect of Cdc42p on cell polarization. Available evidence suggests that members of the PAK kinase family are involved in the activation of MAP kinase signaling cascades rather than affecting cytoskeleton polarization (Cvrckova et al. 1995; Joneson et al. 1996; Lamarche et al. 1996). WASPrelated molecules are not necessary for actin pol arization in yeast, although they do affect some aspects of cortical actin morphol ogy (Li 1997; D. Mitchell and G.F. Sprague, pers. comm.). Finally, recent work has implicated Bni 1p, a formin-rel ated molecule, as a Cdc42p effector that contributes to actin polarization during mating (Evangelista et al. 1997). BNI1, however, is dispensable for polarization of actin during budding (Jansen et al. 1997), and furthermore, Bni 1p does not bind specifically to Cdc42p but also interacts with the related GTPases Rholp, Rho3p, and Rho4p (Evangelista et al. 1997; Imamura et al. 1997; Kohno et al. 1997).

In contrast, we have presented four lines of evidence that argue strongly that Giclp and Gic2p are Cdc42p effectors critical for controlling cell polarity. First, Giclp and Gic2p bind specifically to Cdc42p-GTP with no detectable affinity for Cdc42p-GDP or related Rho proteins. Second, Gic1p and Gic2p colocalize with Cdc42p to the future bud site or mating projection at times when cytoskeletal polarization is being established. Third, the cell polarization defects exhibited by gic $1 \Delta$ gic $2 \Delta$ cells are similar to those of cdc42 mutants. Finally, and importantly, Gic2p function correlates with Cdc42p binding: Disruption of the Cdc42p-Gic2p interaction eliminates Gic protein function in vivo.

On the basis of these observations, we propose that during the cell cycle or in response to extracellular signals, Cdc42p is converted to the GTP-bound form in a spatially restricted manner. In turn, Cdc42p-GTP binds to Giclp and Gic2p, which contribute toward cytoskeletal polarization (Fig. 9). It is unclear, at present, how Giclp and Gic2p exert these effects, and the GIC sequences provide no obvious clues. Gic proteins may bind cytoskel etal el ements directly, or they may link Cdc42p to key actin or microtubule-binding factors. Although no Gic homologs are yet known from other organisms, we consider it likely that Gic-like proteins link Cdc42p to cell polarity and cytoskeletal organization in higher eukaryotes, as, to date, all known Cdc42-binding proteins are conserved broadly.

The effects of Cdc42p on the cytoskel etal organization and MAP kinase signaling are mediated through distinct effectors

Evidence presented here and elsewhere confirms the view that $\mathrm{Cdc} 42 \mathrm{p}$ mediates its effects on the cytoskeleton and signal transduction pathways through distinct effectors. PAK-related kinases function upstream of

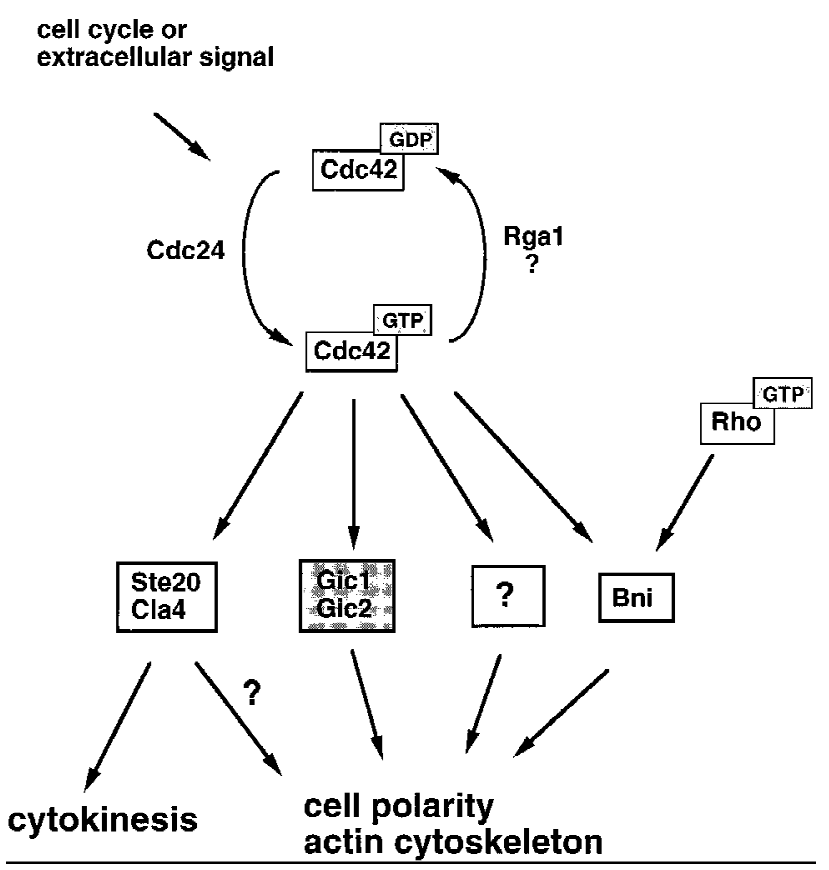

Figure 9. A pathway for cytoskeletal polarization mediated by Cdc42p in yeast. Cell cycle progression or extracellular signals lead to the conversion of GDP to GTP on Cdc42p, possibly by activation of the exchange factor Cdc24p. GTP-Cdc42p then binds and thereby localizes the effectors Giclp and Gic2p to sites of polarized growth, which in turn contribute to polarization of the actin cytoskeleton. Cdc42p might exert some of its effects on the cytoskel eton not only through Giclp and Gic2p but also through other targets including Bnilp, Ste20p, and Cla4p. Bnilp is known to interact also with other members of the Rho-GTPase family.

MAP kinase signaling cascades (Leberer et al. 1992), and Cdc42p has been shown to bind and thereby activate these kinases in vitro ( $M$ anser et al. 1994; Martin et al. 1995; Simon et al. 1995). Available evidence, however, suggests that PAK-like kinases are not sufficient to account for cytoskeletal polarization mediated by Cdc42p, as a mutant form of $\mathrm{Cdc} 42 \mathrm{p}$ that is unable to bind PAK kinases and fails to activate the JNK/SAPK kinase pathway fully promotes actin rearrangements when injected into fibroblasts (Joneson et al. 1996; Lamarche et al. 1996). Consistent with these observations, yeast cells lacking the two PAK-related kinases Ste20p and Cla4p are able to polarize their actin cytoskel eton (C vrckova et al. 1995). In contrast, we show here that Giclp and Gic2p are essential for cell polarization in yeast, but that Giclp and Gic2p are dispensible for pheromone-induced signal transduction, indicating that these $\mathrm{Cdc} 42 \mathrm{p}$-targets are specific for mediating cytoskeletal rearrangements.

Cdc42p may regulate the cytoskeleton through multiple effectors

The evidence presented here firmly establishes that the Gic proteins are Cdc42p targets controlling cytoskeletal 
polarization. The Gic proteins, however, are not likely to be the sole cytoskel etal effectors of Cdc42p. First, cdc42 mutant cells are nonviable, whereas cells lacking both Giclp and Gic2p are slow growing. Second, overexpression of either Cdc42p or Bem1p was able to at least partially restore the growth defect of gic1 $\Delta$ gic $2 \Delta$ cells, showing that increased levels of Cdc42p and Bem1p can reduce the need for the Gic proteins. In contrast, overexpression of either Gic protein failed to restore growth of cells lacking functional Cdc42p. Taken together, these results raise the possibility that $\mathrm{Cdc} 42 \mathrm{p}$ and related GTPases direct cytoskeletal polarization, not through a single effector, but by signaling through a combination of effectors, each of which controls a parameter of actin or microtubule dynamics (Fig. 9). Together, Gic proteins and other factors would account for the essential role of Cdc42p in establishing axes of cell polarization.

\section{Materials and methods}

Genetic, recombinant, and database search methods

Standard yeast growth conditions and genetic manipulations were used (Rose and Fink 1990). Yeast transformations were performed by the lithium acetate method (Ito et al. 1983). Standard procedures were used for recombinant DNA manipulations (Sambrook et al. 1989; Ausubel et al. 1991). PCR reactions were performed by use of the Expand polymerase kit as recommended by the manufacturer (Boehringer Mannheim). Products were purified with the Wizard PCR purification kit according to the instructions of the manufacturer (Promega). Database searches were performed by use of the SGD (Stanford University) and the NCBI BLAST programs ( $\mathrm{N}$ ational Institutes of Health).

\section{GIC cloning and deletions}

The GIC1 and GIC2 genes were cloned by PCR of genomic DN A from a haploid S288C-derived yeast strain (MATa ade2101 , ura3-52, trp1- $\Delta 1$, his3 $\Delta 200$, leu $2 \Delta$, lys2-801) and the following oligonucleotides:

GIC1: OTP358 (5'-ATTTGCGGCCGCCGTCATCAGGAGTTCGAGGTCCAGAGGCATTGTTATCGG-3') and oTP359 (5'ATAAAGCTTCATTACGAGGAAACTATGGTGAAGATTACTGGG-3'); GIC2: OTP356 (5'-GCATTGCGGCCGCTTATAATTTTGGCGTTCAGCAAGCGCGCGG-3') and oTP357 (5'GTTAATTCGAAGATATAATAAACGAATGTATGGGATAACGCC-3'). An internal BamH1-Sphl fragment of the GIC1 gene was replaced with the $U$ RA 3 gene to generate the plasmid pMJ33. The GIC2 deletion construct was produced by removing an internal Spel-BamHI fragment of the GIC2 gene, and replacing it with the full length LEU 2 gene to generate the pBSK+ based plasmid, pMJ43. The resulting disruption constructs were excised from pMJ43 and pMJ33 and used to generate heterozygous diploid gic $2 \Delta::$ LEU 2 and gic $1 \Delta::$ U RA 3 strains in the W303 background (K700: MAT a/ $\alpha$ ade2-1, trp1-1, leu2-3, 112, his311,15 , ura3, GAL, psi ${ }^{+}$) by single step gene replacement (Rothstein 1991). Haploid gic1::U RA3 and gic2::LEU 2 segregants of opposite mating type were obtained by sporulation and used to generate a diploid strain (YM P1053), which was then sporulated to isolate gicl gic2 double deletion mutants. Tetrads were dissected on YPD medium with $1 \mathrm{~m}$ sorbitol and grown at $25^{\circ} \mathrm{C}$.

Construction of the $\mathrm{crib}^{-}$and truncation mutations of GIC2

The gic2 ${ }^{\text {crib- }}$ al lele was generated by mutating three consensus
CRIB amino acids (I134, S135, and P137) to alanine residues by two-step PCR with the following ol igonucl eotide combinations: OTP356 and oTP434 (5'-GTGAAATATGTTGAAAATCAAATGCTGTGGCG-3'); OTP429 (5'-GGTGCCGCCACAGCATTTGATTTTCAACATATTTCAC-3') and oTP357. The mutated Crib- GIC2 gene was sequenced, and subcloned into pJ G4-5 for two hybrid experiments (generating pMJ177), as well as several other yeast vectors (pRS314, pRS424, YEp352; Sikorski and Hieter 1989).

The amino-terminal fragment of GIC2 (amino acid residues 1-208) was amplified by PCR with oligonucleotides OTP409: (5'-ACTGGAATTCAATATGACTAGTGCAAGTATTACC-3') and oTP423: (5'-ACGCTCGAGTCATAGTCTTGATGTCTTATTTTCGTGCG-3'), and subcloned into the two hybrid vector pJG4-5 (generating pMJ64) and a GAL1 expression vector to generate $\mathrm{pMJ} 127$.

\section{Construction of epitope-tagged Giclp, Gic2p, and Cdc42p}

Epitope-tagged versions of Giclp and Gic2p containing the influenza hemagglutinin (HA) epitope (YPYDVPDYA) fused to the carboxyl terminus of each protein were constructed by use of PCR and the following oligonucleotide pairs: GIC1: (5'-CGCGAATTCGCGAAAAGACAACAAC-3') and (5'-GCTCTAGATTAAGCGTAGTCTGGGACGTCGTATGGGTAGGTATTTCGAGGAGTACTAGTTTC-3'); GIC2: (5'-CGAGATCTAGATGTTGCCTATTTCTCG-3'), and (5'-GCTCTAGATTAAGCGTAGTCTGGGACGTCGTATGGGTAAGTTTGCAGGGGCTCGAGCTGG-3'). Isolated PCR products containing 300 bp of the endogenous $\mathrm{GIC} 1$ and GIC2 promoters were derived directly from SEY 6210 genomic DNA and cloned into pRS313, pRS314, YEp351, and Yep352-based plasmids as EcoRI-Xbal or $X$ bal fragments. The integrity of the constructs was confirmed by sequencing and Western blotting. Plasmids expressing either HA-Giclp or HA-Gic2p were found to fully complement both the growth and morphology defects associated with gic $1 \Delta$ gic $2 \Delta$ mutants. Construction of an amino-terminal epitope-tagged Cdc42p in a pRS315-based plasmid was generated by use of PCR and oligonucleotides (5'-CGGGATCCTATTAGCTCTTCCACAAAATGTACCCATACGACGTCCCAGACTACGCTCAAACGCTAAAGTGTGTTGTTGTCGG-3') and (5'-GCTCTAGACGGGCATATACTAATATGACTACA-3'). PCR products were cloned into the pRS315 vector containing 500 bp of the endogenous CDC 42 promoter as BamHI/Xbal fragments, and anal yzed by Western blotting. Centromeric plasmids expressing HA-Cdc42p fully complemented a cdc42::TRP1 disrupted strain in plasmid shuffle experiments.

\section{Production of polyclonal Anti-Gic2p antisera}

Polyclonal anti-Gic2p antibodies were generated against the full length Gic2p coding sequence cl oned into pG EX-4T (Pharmacia) and expressed as a GST-fusion protein. Soluble GST-Gic2p, purified with glutathione Sepharose (Pharmacia) was used to immunize rabbits (Elevage Scientifique des Dombes, France). Antibodies were affinity-purified against GST-Gic2p as described (Harlow and Lane 1988). Standard procedures were used for yeast cell extract preparation and immunoblotting (Peter et al. 1993). Antibodies are specific to Gic2p as no signal is detected in extracts from gic $2 \Delta$ cells (data not shown).

\section{Cell synchronization}

To release cells from a cdc15-2 block, cells were grown to exponential phase in YPD medium and then shifted to $37^{\circ} \mathrm{C}$ for 2 hr. Cells were released by shifting the culture to $25^{\circ} \mathrm{C}$, and 
aliquots were taken at 15-min intervals. Protein extracts were prepared as described above. Cell cycle synchrony was monitored by fluorescence-activated cell sorting analysis and microscopic determination of the budding index.

\section{Two-hybrid assays}

Two-hybrid assays were performed in yeast strain EGY 48 transformed with pEG202-based plasmids expressing LexA DNAbinding domain fusions, and pJG4-5-based plasmids containing transcriptional activation domain fusions (Gyuris et al. 1993). LexA-GTPase fusions all contain carboxy-terminal Cys to Ser substitutions that prevent prenylation. LacZ reporter activity was measured as described previously (Stern et al. 1984).

\section{Cdc42p-binding assays}

Gic2p affinity matrices were prepared as follows: Extracts of yeast expressing Gic2-HAp from the GAL1 promoter were prepared in TNE450 buffer (450 mM N aCl, $10 \mathrm{~mm}$ EDTA, $50 \mathrm{~mm}$ Tris- $\mathrm{HCl}$ at $\mathrm{pH} 7.5,0.1 \% \mathrm{~N} \mathrm{P}-40$ ) and depleted of Gic2-HAp by use of 11HA monoclonal antibodies (Babco, Berkeley, CA) covalently coupled to protein G-Sepharose (Peter et al. 1996) (Pharmacia). Gic2-HAp columns were washed three times with TMT $(10 \mathrm{~mm}$ Tris at pH 7.5, $10 \mathrm{~mm} \mathrm{M} \mathrm{gCl}, 1 \mathrm{~mm}$ DTT, $0.1 \%$ Triton $X-100)$ prior to $C d c 42 p$ binding. $C d c 42 p$ and $C d c 42 p^{\top 35 A}$ proteins were produced in Escherichia coli strain NB42 as $6 \mathrm{H}$ is fusion proteins by use of the pTrcHis vector (Invitrogen) and purified on $\mathrm{CO}^{2+}$ Sepharose-6B columns coupled with iminodiacetic acid (Sigma). Purified Cdc42p was prel oaded with GTP- $\gamma S$ or GDP, as described (Park et al. 1993), and incubated for $1 \mathrm{hr}$ at $4^{\circ} \mathrm{C}$ with affinity matrix in $200 \mu \mathrm{l}$ of buffer $\mathrm{B}(10 \mathrm{~mm}$ Tris at $\mathrm{pH}$ 7.5, $85 \mathrm{~mm} \mathrm{NaCl}, 6 \mathrm{~mm} \mathrm{M} \mathrm{gCl}_{2}, 10 \%$ glycerol) containing 0.6 $\mathrm{mM}$ GTP- $\gamma \mathrm{S}$, or $0.6 \mathrm{mM}$ GDP. After four washes with TMT buffer, Cdc42p was el uted with $100 \mu$ of gel sample buffer and detected by immunoblotting with $\mathrm{Cdc} 42 \mathrm{p}$-specific antisera ( $\mathrm{Pe}$ ter et al. 1996).

\section{Immunofluorescence}

Actin and microtubule staining was performed on cells fixed and treated by standard methods (Pringle et al. 1991). Actin was visualized by use of rhodamine-conjugated phalloidin (M olecular Probes) at a concentration of $1 \mathrm{mg} / \mathrm{ml}$, and microtubules were detected with the YOL1/34 monoclonal antibody (Accurate) and FITC-conjugated goat anti-rat secondary antibodies (Jackson Labs) at 1/1000 dilution. The DNA stain Hoechst (Sigma) was used at a final concentration of $0.01 \mathrm{mg} / \mathrm{ml}$.

Immunofluorescence microscopy of the Gic proteins was performed in W303 cells on fully complementing carboxy-terminally HA epitope-tagged versions expressed under their own promoters in gic $1 \Delta$ gic $2 \Delta$ cells from the pRS313 or pRS314based centromeric plasmids, respectively. Amino-terminallytagged Cdc42p was expressed from its own promoter in the pRS315 plasmid in wild-type hapl oid strain 1241-2D (Chant and Hersowitz 1991). HA-tagged proteins were visual ized (Pringle et al. 1991; Brown et al. 1994) with the 11 HA monoclonal (Babco) and CY3-conjugated goat anti-mouse secondary antibodies (Jackson Labs) at $1 / 1000$ dilutions. Pheromone treated cells were exposed to $4 \mathrm{mg} / \mathrm{ml}$ of synthetic $\alpha$-factor (Sigma) for $1.5 \mathrm{hr}$. For Figure 7C, HA-tagged Gic2p and Gic2 $\mathrm{p}^{\text {crib- }}$ were produced from multicopy YEp351-based plasmids in a wild-type strain.

\section{Mating assays}

Mating assays were performed with the tester strains IH1793 (MAT $\alpha$, Iys1) and IH2625 (MAT $\alpha$, Iys1, far1-c) as described
(Valtz and Peter 1997). Shmoo morphology was examined after addition of $10^{-6} \mathrm{M} \alpha$-factor to $3 \mathrm{ml}$ of log phase cultures for $3 \mathrm{hr}$ at $25^{\circ} \mathrm{C}$. For cell cycle arrest (halo) assays, $10^{3}-10^{4}$ cells were plated on Y PD-sorbitol plates (1M sorbitol). Ten micrograms of $\alpha$-factor in $20 \mu \mathrm{l}$ of $0.01 \mathrm{~m} \mathrm{HCl}$ was spotted on a sterile filter disc (Schleicher and Schuell) and placed on plates, which were then incubated for 3 days at $25^{\circ} \mathrm{C}$.

\section{Acknowledgments}

The authors would like to thank the members of each lab for hel pful discussions, M. van Lohuizen and C. Boone for strains and plasmids, K. Hofmann for help with computer analysis, and A. Rushforth for help with early aspects of this work. We acknowledge D. Mitchell and G. Sprague for sharing unpublished results, and J. Philips, B. A mati, and V. Simanis for critical reading of the manuscript. J.B. received support from a $\mathrm{N}$ ational Institutes of Health (N IH) Postdoctoral Fellowship, and J.C. has operating grants from the NIH and the Searle Family/Chicago Community Trust. M.P. is supported by the Swiss $\mathrm{N}$ ational Science Foundation, the Swiss Cancer League, and a Helmut Horten Incentive A ward.

The publication costs of this article were defrayed in part by payment of page charges. This article must therefore be hereby marked "advertisement" in accordance with 18 USC section 1734 solely to indicate this fact.

\section{References}

Adams, A.E.M., D.I. Johnson, R.M. Longnecker, B.F. Sloat, and J.R. Pringle. 1990. CDC42 and CDC43, two additional genes involved in budding and the establishment of cell polarity in the yeast Saccharomyces cerevisiae. J. Cell Biol. 111: 131142.

Aspenström, P., U. Lindberg, and A. Hall. 1996. Two GTPases, Cdc42 and Rac, bind directly to a protein implicated in the immunodeficiency disorder Wiskott-Aldrich syndrome. Curr. Biol. 6: 70-75.

Ausubel, F.M., R. Brent, R.E. Kingston, D.D. Moore, J.G. Seidman, J.A. Smith, and K. Struhl. 1991. Current protocols in molecular biology. Greene Publishing Associates/WileyInterscience, N ew York, NY.

Bagrodia, S., B. Derijard, R.J. Davis, and R.A. Cerione. 1995. Cdc42 and PAK-mediated signalling leads to Jun kinase and p38 mitogen-activated protein kinase activation. J. Biol. Chem. 270: 27995-27998.

Brill, S., S. Li, C.W. Lyman, D.M. Church, J.J. Wasmuth, L. Weissbach, A. Bernards, and A.J. Snijders. 1996. The Ras GTPase-activating-protein-related human protein IQGAP2 harbors a potential actin binding domain and interacts with calmodulin and Rho family GTPases. Mol. Cell. Biol. 16: 4869-4878.

Brown, J.L., H. Bussey, and R.C. Stewart. 1994. Yeast Skn7p functions in a eukaryotic two-component regulatory pathway. EMBO J. 13: 5186-5194.

Brown, J.L., L. Stowers, M. Baer, J.A. Trejo, S. Coughlin, and J. Chant. 1996. Human Ste20 homologue hPAK1 links GTPases to the JNK MAP kinase pathway. Curr. Biol. 6: 598605.

Burbel O, P.D., D. Drechsel, and A. Hall. 1995. A conserved binding motif defines numerous candidate target proteins for both Cdc42 and Rac GTPases. J. Biol. Chem. 270: 2907129074.

Chant, J. 1996. Generation of cell polarity in yeast. Curr. O pin. Cell Biol. 8: 557-565. 
Chant, J. and I. Herskowitz. 1991. Genetic control of bud site selection in yeast by a set of gene products that constitute a morphogenetic pathway. Cell 65: 1203-1212.

Chenevert, J., K. Corrado, A. Bender, J. Pringle, and I. Herskowitz. 1992. A yeast gene (BEM 1) necessary for cell polarization whose product contains two SH3 domains. Nature 356: 7779.

Chou, M.M. and J. Blenis. 1996. The 70KDa S6 kinase complexes with and is activated by the Rho family $G$ proteins Cdc42 and Rac1. Cell 85: 573-583.

Coso, O.A., M. Chiariello, J.C. Yu, H. Teramoto, P. Crespo, N. Xu, T. Miki, and J.S. Gutkind. 1995. The small GTP-binding proteins Racl and Cdc42 regulate the activity of the JNK/ SAPK signalling pathway. Cell 81: 1137-1146.

Cvrckova, F., C. De Virgilio, E. Manser, J.R. Pringle, and K. $\mathrm{N}$ asmyth. 1995. Ste20-like protein kinases are required for normal localization of cell growth and for cytokinesis in budding yeast. Genes \& Dev. 9: 1817-1830.

Dorer, R., P.M. Pryciak, and L.H. Hartwell. 1995. Saccharomyces cerevisiae cells execute a default pathway to select a mate in the absence of pheromone gradients. J. Cell Biol. 131: 845-861.

Drubin, D.G. and W.J. Nelson. 1996. Origins of cell polarity. Cell 84: 335-344.

Evangelista, M., K. Blundell, C.J. Chow, N. Adames, J.R. Pringle, M. Peter, and C. Boone. 1997. Bnilp, a yeast formin linking Cdc42p and the actin cytoskel eton during polarized morphogenesis. Science 276: 118-122.

Fields, S. and O. Song. 1989. A novel genetic system to detect protein-protein interactions. Nature 340: 245-246.

Frazier, J.A. and C.M. Field. 1997. Are FH proteins local organizers? Curr. Biol. 7: 414-417.

Glotzer, M. and A.A. Hyman. 1995. The importance of being polar. Curr. Biol. 5: 1102-1105.

Gyuris, J., E. Golemis, H. Chertkov, and R. Brent. 1993. Cdi 1, a human $\mathrm{Gl}$ and $\mathrm{S}$ phase protein phosphatase that associates with Cdk2. Cell 75: 791-803.

Hall, A. 1994. Small GTP-binding proteins and the regulation of the actin cytoskeleton. Annu. Rev. Cell Biol. 10: 31-54.

Harlow, E. and D. Lane. 1988. Antibodies: A laboratory manual. Cold Spring Harbor Laboratory, Cold Spring Harbor, NY.

Hart, M.J., M.G. Callow, B. Souza, and P. Polakis. 1996. IQGAP1, a calmodulin-binding protein with a RasGAP-related domain, is a potential effector for $\mathrm{Cdc} 42 \mathrm{Hs}$. EMBO J. 15: 2997-3005.

Herskowitz, I. 1995. MAP kinase pathways in yeast: For mating and more. Cell 80: 187-197.

Hill, C.S., J. Wynne, and R. Treisman. 1995. The Rho family GTPases RhoA, Rac1, and CDC42Hs regulate transcriptional activation by SRF. Cell 81: 1159-1170.

Imamura, H., K. Tanaka, T. Hihara, M. Umikawa, T. Kamei, K. Takahashi, T. Sasaki, and Y. Takai. 1997. Bnilp and Bnrlp: Downstream targets of the Rho family small G-proteins which interact with profilin and regulate actin cytoskel eton in Saccharomyces cerevisiae. EMBO J. 16: 2745-2755.

Ito, H., Y. Fukuda, K. Murata, and A. Kimura. 1983. Transformation of intact yeast cells treated with alkali cations. J. Bacteriol. 153: 163-168.

Jansen, R.P., C. Dowzer, C. Michaelis, M. Galova, and K. N asmyth. 1996. Mother cell-specific HO expression in budding yeast depends on the unconventional myosin myo4p and other cytoplasmic proteins. Cell 84: 687-697.

Johnson, D.I. and J.R. Pringle. 1990. Molecular characterization of CDC42, a Saccharomyces cerevisiae gene involved in the development of cell polarity. J. Cell Biol. 111: 143-152.
Joneson, T., M. McDonough, D. Bar-Sagi, and L. Van Aelst. 1996. Rac regulation of actin polymerization and proliferation by a pathway distinct from Jun kinase. Science 274: 1374-1376.

Kolluri, R., K.F. Tolias, C.L. Carpenter, F.S. Rosen, and T. Kirchhausen. 1996. Direct interaction of the Wiskott-Aldrich syndrome protein with the GTPase Cdc42. Proc. Natl. Acad. Sci. 93: 5615-5618.

Kohno, H., K. Tanaka, A. Mino, M. Umikawa, H. Imamura, T. Fujiwara, Y. Fujita, K. Hotta, H. Qatoda, T. Watanabe, Y. Ohya, and Y. Takai. 1996. Bnilp implicated in cytoskel etal control is a putative target of Rholp small GTP binding protein in Saccharomyces cerevisiae. EMBO J. 15: 6060-6068.

Kozma, R., S. A hmed, A. Best, and L. Lim. 1995. The Ras-rel ated protein $\mathrm{Cdc} 42 \mathrm{Hs}$ and bradykinin promote formation of peripheral actin mikrospikes and filopodia in Swiss 3T 3 fibroblasts. Mol. Cell Biol. 15: 1942-1952.

Kuroda, S., M. Fukata, K. Kobayashi, M. N akafuku, N. N omura, A. Iwamatsu, and K. Kaibuchi. 1996. Identification of IQGAP as a putative target for the small GTPases, Cdc42 and Racl. J. Biol. Chem. 271: 23363-23367.

Lamarche, N., N. Tapon, L. Stowers, P.D. Burbelo, P. Aspenstrom, T. Bridges, J. Chant, and A. Hall. 1996. Rac and Cdc42 induce actin polymerization and $\mathrm{G} 1$ cell cycle progression independently of $165^{\text {PAK }}$ and the JNK/SAPK MAP kinase cascade. Cell 87: 519-529.

Leberer, E., D. Dignard, D. Harcus, D.Y. Thomas, and M. Whiteway. 1992. The protein kinase homologue Ste20p is required to link the yeast pheromone response G-protein beta gamma subunits to downstream signalling components. EMBO J. 11: 4815-4824.

Leberer, E., C. Wu, T. Leeuw, A. Fourest-Lieuvin, J.E. Segall, and D.Y. Thomas. 1997. Functional characterization of the Cdc42 binding domain of yeast Ste20p protein kinase. EMBO J. 16: 83-97.

Leeuw, T., A. Fourest-Lieuvin, C. Wu, J. Chenevert, K. Clark, M. Whiteway, D.Y. Thomas, and E. Leberer. 1995. Pheromone response in yeast: Association of Bemlp with protein of the MAP kinase cascade and actin. Science 270: 12101213.

Li, R. 1997. Bee 1, a yeast protein with homology to WiscottAldrich syndrome protein, is critical for the assembly of cortical actin cytoskeleton. J. Cell Biol. 136: 649-658.

Lyons, D.M., M.C. Mahanty, K.-Y. Choi, M. Manandhar, and E.A. Elion. 1996. The SH3-domain protein Bemlp coordinates mitogen-activated protein kinase cascade activation with cell cycle control in Saccharomyces cerevisiae. Mol. Cell Biol. 16: 4095-4106.

Manser, E., T. Leung, H. Salihuddin, Z.S. Zhao, and L. Lim. 1994. A brain serine/threonine protein kinase activated by Cdc42 and Rac1. Nature 367: 40-46.

Markus, S., A. Polverino, E. Chang, D. Robbins, M.H. Cobb, and M.H. Wigler. 1995. Shk1, a homolog of the Saccharomyces cerevisiae Ste20 and mammalian p65PAK protein kinases, is a component of a Ras/C dc42 signalling module in the fission yeast Schizosaccharomyces pombe. Proc. Natl. Acad. Sci. 92: 6180-6184.

Martin, G.A., G. Bollag, F. McCormick, and A. Abo. 1995. A novel serine kinase activated by Rac1/CDC42Hs-dependent autophosphorylation is related to PAK65 and STE20. EMBO J. 14: 1970-1978.

McCallum, S.J., W.J. Wu, and R.A. Cerione. 1996. Identification of a putative effector for $\mathrm{Cdc} 42 \mathrm{Hs}$ with high sequence similarity to the RasGAP-rel ated protein IQGAPI and a Cdc42Hs binding partner with similarity to IQGAP2. J. Biol. Chem. 271: 21732-21737. 
Minden, A., A. Lin, F.X. Claret, A. Abo, and M. Karin. 1995. Selective activation of the JNK signalling cascade and c-Jun transcriptional activity by the small GTPases Rac and Cdc42Hs. Cell 81: 1147-1157.

Mösch, H.-U., R.L. Roberts, and G.R. Fink. 1996. Ras2 signals via the Cdc42/Ste20/mitogen-activated protein kinase module to induce filamentous growth in Saccharomyces cerevisiae. Proc. Natl. Acad. Sci. 93: 5352-5356.

Nobes, C.D. and A. Hall. 1995. Rho, Rac, and Cdc42 GTPases regulate the assembly of multimolecular focal complexes associated with actin stress fibers, lamellipodia, and filopodia. Cell 81: 53-62.

Park, H.O., J. Chant, and I. Herskowitz. 1993. BU D2 encodes a GTPase-activating protein for Bud1/Rsrl necessary for proper bud-site selection in yeast. Nature 365: 269-274.

Park, H.O., E. Bi, J.R. Pringle, and I. Herskowitz. 1997. Two active states of the Ras-related Bud1/Rsr1 protein bind to different effectors to determine yeast cell polarity. Proc. Natl. Acad. Sci. 94: 4463-4468.

Peter, M., A. Gartner, J. Horecka, G. Ammerer, and I. Herskowitz. 1993. FAR I links the signal transduction pathway to the cell cycle machinery in yeast. Cell 73: 747-760.

Peter, M., A.M. N eiman, H.-O. Park, M. van Lohuizen, and I. Herskowitz. 1996. Functional analysis of the interaction be tween the small GTP binding protein Cdc42 and the Ste20 protein kinase in yeast. EMBO J. 15: 7046-7059.

Peterson, J., Y. Zheng, L. Bender, R. M eyers, R. Cerione, and A. Bender. 1994 Interactions between the bud emergence proteins Bem1p and Bem2p and Rho-type GTPases in yeast. J. Cell Biol. 127: 1395-1406.

Pringle, J.R., A.E.M. Adams, D.G. Drubin, and B.K. Haarer. 1991. Immunofluorescence methods for yeast. Methods Enzymol. 194: 565-602.

Pringle, J.R., E. Bi, H.A. Harkins, J.E. Zahner, C. De Virgilio, J. Chant, K. Corrado, and H. Fares. 1995. Establishment of cell polarity in yeast. Cold Spring Harbor Symp. Quant. Biol. 60: 729-744.

Ramer, S.W. and R.W. Davis. 1993. A dominant truncation allele identifies a gene, STE20, that encodes a putative protein kinase necessary for mating in Saccharomyces cerevisiae. Proc. Natl. Acad. Sci. 89: 452-456.

Ridley, A.J. 1995 Rho-related proteins: Actin cytoskeleton and cell cycle.Curr. Opin. Genet. Dev. 5: 24-30.

Rose, M.D. and G.R. Fink. 1990. Methods in yeast genetics, pp. 119-187. Cold Spring Harbor Laboratory Press, Cold Spring Harbor, NY.

Rothstein, R. 1991. Targeting, disruption, replacement, and allele rescue: Integrative DN A transformation in yeast. Methods Enzymol. 194: 281-301.

Sambrook, J., E.F. Fritsch, and T. Maniatis. 1989. Molecular cloning: A laboratory manual, 2nd edition. Cold Spring Harbor Laboratory Press. Cold Spring Harbor, NY.

Sikorski, R.S. and P. Hieter. 1989. A system of shuttle and yeast host strains designed for efficient manipulation of DNA in Saccharomyces cerevisiae. Genetics 122: 19-27.

Simon, M.N., C. De Virgilio, B. Souza, J.R. Pringle, A. Abo, and S.I. Reed. 1995. Role for the Rho-family GTPase Cdc42 in yeast mating-pheromone signal pathway. Nature 376: 702705.

Sloat, B.F. and J.R. Pringle. 1978 A mutant of yeast defective in cellular morphogenesis. Science 200: 1171-1173.

Stern, M., R. Jensen, and I. Herskowitz. 1984. Five SWI genes are required for expression of the $\mathrm{HO}$ gene in yeast. J. Mol. Biol. 178: 853-868.

Stevenson, B.G., B. Ferguson, C. De Virgilio, E. Bi, J.R. Pringle, G. Ammerer, and G.F. Sprague, Jr. 1995. Mutation of RGA 1, which encodes a putative GTPase-activating protein for polarity-establishment protein $\mathrm{Cdc} 42$, activates the pheromone-response pathway in the yeast Saccharomyces cerevisiae. Genes \& Dev. 9: 2949-2963.

Stowers, L., D. Yelon, L.J. Berg, and J. Chant. 1995. Regulation of the polarization of $T$ cells towards antigen-presenting cells by Ras-related GTPase CDC42. Proc. Natl. Acad. Sci. 92: 5027-5031.

Symons, M . 1995. The Rac and Rho pathways as a source of drug targets for Ras-mediated malignancies. Curr. O pin. Biotech. 6: 668-674.

- - 1996. Rho family GTPases: The cytoskeleton and beyond. Trends Biochem. Sci. 21: 178-181.

Symons, M., J.M.J. Derry, B. Karlak, S. Jiang, V. Lemahieu, F. M cCormick, U. Francke, and A. A bo. 1996. Wiskott-Aldrich syndrome protein, a novel effector for the GTPase CDC42Hs, is implicated in actin polymerization. Cell 84: 723-734.

Trueheart, J., J.D. Boeke, and G.R. Fink. 1987. Two genes required for cell fusion during yeast conjugation: Evidence for a pheromone-induced surface protein. Mol. Cell Biol. 7: 2316-2328.

Valtz, N. and M. Peter. 1997. Functional analysis of FAR1 in yeast. In Cell cycle control. Methods Enzymol. 283: 350365.

Valtz, N., M. Peter, and I. Herskowitz. 1995. FAR1 is required for oriented polarization of yeast cells in response to mating pheromones. J. Cell Biol. 131: 863-873.

Zhang, S., J. Han, M.A. Sells, J. Chernoff, U.G. Knaus, R.J. Ulevitch, and G.M. Bokoch. 1995. Rho family GTPases regulate p38 mitogen-activated protein kinase activation. J. Biol. Chem. 270: 23934-23936.

Zhao, Z. S., T. Leung, E. Manser, and L. Lim. 1995. Pheromone signalling in Saccharomyces cerevisiae requires the small GTP-binding protein Cdc42 and its activator CDC24. Mol. Cell Biol. 15: 5246-5257.

Zheng, Y., M.J. Hart, K. Shinjo, T. Evans, A. Bender, and R.A. Cerione. 1993 Biochemical comparison of the Saccharomyces cerevisiae Bem2 and Bem3 proteins. J. Biol. Chem. 268: 24629-24634.

Ziman, M., D. Preuss, J. Mulholland, J.M. O'Brien, D. Botstein, and D.I. Johnson. 1993. Subcellular localization of Cdc42, a Saccharomyces cerevisiae GTP-binding protein involved in the control of cell polarity. Mol. Cell. Biol. 4: 1307-1316. 


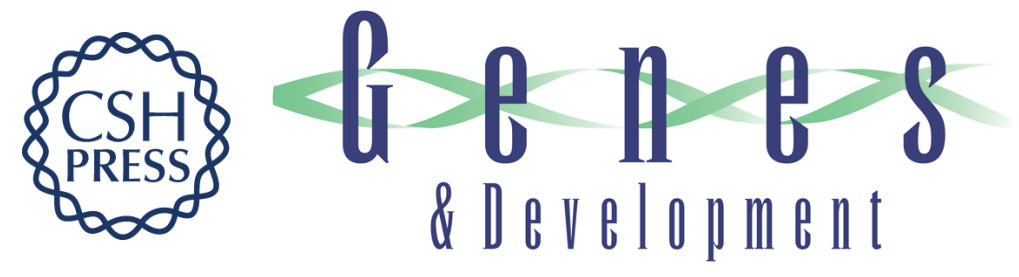

\section{Novel Cdc42-binding proteins Gic1 and Gic2 control cell polarity in yeast}

Jeffrey L. Brown, Malika Jaquenoud, Marie-Pierre Gulli, et al.

Genes Dev. 1997, 11:

Access the most recent version at doi:10.1101/gad.11.22.2972

References

This article cites 70 articles, 33 of which can be accessed free at: http://genesdev.cshlp.org/content/11/22/2972.full.html\#ref-list-1

\section{License}

Email Alerting

Receive free email alerts when new articles cite this article - sign up in the box at the top Service right corner of the article or click here.

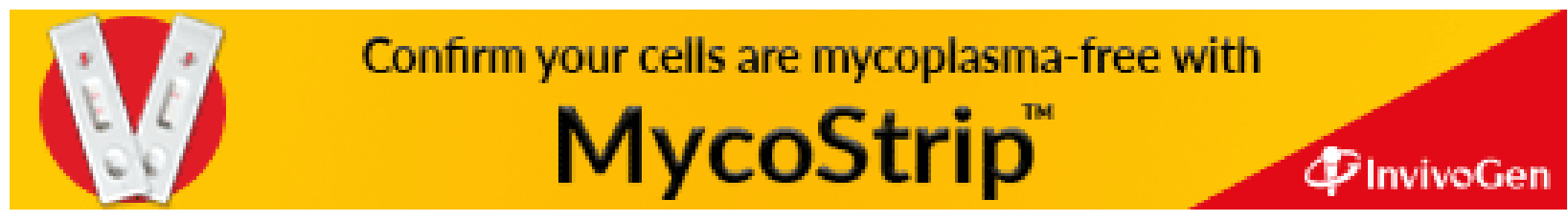

